\title{
Is the Human Being Redeemable? A Meditation on Rosenzweig's Claim That Death Is Very Good
}

\author{
Agata Bielik-Robson \\ University of Nottingham, Nottingham, UK \\ Agata.Bielik-Robson@nottingham.ac.uk
}

\begin{abstract}
In this article I claim there is no contradiction involved in Franz Rosenzweig's love of life and his apology for death: what he loves and wants us to love is the finite life, life offered in its finitude which should in the end appear as enough - that is, sufficient and fit for everything we could want from life, redemption included. The beyond toward which death as the end gestures is not a promise of immortality, offering a transcendence in temporal terms infinitely prolonged. The will "to stay, to live," of which Rosenzweig speaks in the opening paragraph of The Star of Redemption, is the drive characteristic of another finitude: desiring and investing in life, without, at the same time, wishing to prolong itself into infinity.
\end{abstract}

\section{Keywords}

redemption - Franz Rosenzweig - finitude - death - neighborly love - connection

Only connect! ... Only connect the prose and the passion, and both will be exalted, and human love will be seen at its height. Live in fragments no longer. Only connect, and the beast and the monk, robbed of the isolation that is life to either, will die.

E. M. FORSTER, Howards End 
At the end of the first part of The Star of Redemption, devoted to the concept of creation, Franz Rosenzweig famously states about death that, unlike other created things that are just good, death is very good and as such is the true crown and gem of the creaturely world: not something to be deplored as the sign of transience "reeking of decay," but to be praised and cherished as the finishing touch to the enterprise of creation:

Within the framework of the universal Yes of Creation which carries all the Singular on its broad back, a domain is delimited which receives a different Yes, a Yes qualified by "very," different from everything else, something that, while in the Creation points beyond Creation. This "very" which announces a trans-creation right within Creation, within the world, a beyond of the world, something other than life while belonging to life and only to life, created at the same time as life, as its ending point, and yet allowing life to have an inkling of a fulfillment beyond it: this is death. The created death of the creature is at the same time the sign that announces the Revelation of life which transcends that of the simple creature. Death, which is for each created thing the fulfillment of his total thingliness, imperceptibly pushes the Creation back into the past and so transforms it into a silent and permanent prediction of the miracle of its renewal. That is why, concerning the sixth day of Creation, it is not said that it was "good," but "Look, very good!" "Very good," our men of old teach us, very good - this is death. ${ }^{1}$

A tall order: to praise death - and most of the commentators found it indeed far too tall, in fact more than that: simply contradictory to Rosenzweig's main thrust of going into life!, which constitutes the main imperative of the Star, graphically formatted as an arrow pointing in the direction of die Mitte des Lebens. ${ }^{2}$ But I would like to show that there is no contradiction involved in Rosenzweig's love of life and his apology for death: what he loves and wants us to love is the finite life, life offered in its finitude which should in the end appear as enough - that is, sufficient and fit for everything we could want from life, redemption included. The beyond toward which death as the end gestures is not a promise of immortality, offering a transcendence in temporal terms infinitely prolonged. To Rosenzweig's still Hegelian mind, this would be the epitome of "bad infinity," which perpetuates creaturely life

1 Franz Rosenzweig, The Star of Redemption, trans. Barbara Galli (Madison: University of Wisconsin Press, 2005), 168. Henceforth SR.

2 Most notably Zachary Braiterman, "Into Life'??! Franz Rosenzweig and the Figure of Death," AJS Review 23 (1998): 203-221. 
in quantum without transforming it in terms of qualitative "renewal," which is Rosenzweig's main purpose. This renewal can also be framed in Hegel's terms as "the infinite in the finite": redemption takes place either here and now, in the potentiality of the finite moment, or nowhere and never at all - although, as we shall see in a moment, its execution takes a different form than in Hegel's system, too immanentist for Rosenzweig, who longs for the transcendence of eternity, yet not to be confused with the immortal life of an isolated soul.

So, to the question: Is the human being redeemable? Rosenzweig says Yes, but only on the condition that humans relinquish the hope for living on foreverin other words, if they give up on the idea of redemption as personal immortality. More than that, in his understanding of Judaism as the religion of the finite life, Rosenzweig also implies that the wish to stay forever in being is, in fact, the root of all evil. He is not alone in this implication. Levinas's critique of Spinoza goes exactly in this direction: conatus represents for him an egotistic vitalist urge which would have warded off death for ever, if it only could. And even if Levinas is a bit unfair to Spinoza himself, who actually did not believe in the immortality of the soul, his construction of conatus as a pure will of life indeed excludes any inner sense of limitation: the end-death always comes from the outside. ${ }^{3}$

Rosenzweig is less harsh on Spinoza, but he also modifies his notion of conatus: it is no longer a will to live, potentially forever, but a will to remain, which has an idea of a limit already inscribed in itself. The will to remain, therefore, wards off death - but only in the condition of creaturely finitude, "within the earthly itself". ${ }^{4}$ It is a new and subtle proposition, situating itself between the phantasm of life pure and infinite, which Levinas ascribes to Spinoza, on the one hand - and the Heideggerian concept of Sein-zum-Tode, in which life itself is swallowed up by death and the process of the finite living becomes indistinguishable from dying. The will "to stay, to live," of which Rosenzweig speaks in the opening paragraph of the Star, is the drive characteristic of another finitude: desiring and investing in life, without, at the same time, wishing to

3 On Levinas's critique of Spinoza, see Edith Wyschogrod, "Ethics as First Philosophy: Levinas Reads Spinoza," The Eighteenth Century 40 (1999): 195-205. In his defense of Judaism as a religion of the finite life, Rosenzweig finds an unexpected ally in Schopenhauer, even if for the latter it is a sign of its lower spiritual rank when compared to Christianity, which he, as if in the act of overbidding Marcion, perceives as anti-Jewish and "Indian in spirit": "The assumption that man is created out of nothing necessarily leads to the assumption that death is his absolute end. In this respect, therefore, the Old Testament is quite consistent; for no doctrine of immortality is appropriate to a creation out of nothing. New Testament Christianity has such a doctrine, because it is Indian in spirit, and therefore, more than probably, Indian in origin, although only indirectly, through Egypt." Arthur Schopenhauer, The World as Will and Representation, trans. E. F. J. Payne, 2 vols. (New York: Dover, 1969), 2:488.

4 SR, 10. 
prolong itself into infinity; knowing the blessing of the limit, implied by the phrase "very good: this is death," even if death is still bound to inspire fear. Speaking about philosophy, which far too easily removes the "sting of death" by denigrating the very idea of earthly life, Rosenzweig proposes "another exit" from the existential contradiction between the will to remain and the inevitability of death:

For man does not at all want to escape from some chain; he wants to stay, he wants - to live. Philosophy, which commends death to him as its special little shelter and as the splendid opportunity to escape from the narrowness of life, seems to be only jeering at him. Man feels only too well that he is certainly condemned to death, but not to suicide. And it is only suicide that that philosophical recommendation would truly be able to recommend, not the death decreed for all.... For man, there is reserved another exit from the impasse of the nothing than this fall into the yawning of the abyss. Man should not cast aside from him the fear of the earthly; in his fear of death he should - stay. He should stay. He should therefore do nothing other than what he already wants: to stay. The fear of the earthly should be removed from him only with the earthly itself. But as long as he lives on earth, he should also remain in fear of the earthly. ${ }^{5}$

The finite condition demands that the desire "to stay" in life must necessarily be entangled in the desire to remain in the fear of death: no promise of life immortal can - or should - dissolve the creaturely knot. Among later thinkers, the closest to Rosenzweig's intuition is Derrida, for whom the phantasmatic lure of "absolute life" equals "absolute evil" - yet, simultaneously, he also wishes "to stay" in being, provided it does not take the form of the infinite vitalist Wille-zum-Leben, but merely a more modest will-to-survive: survie, just as Rosenzweig's will to remain does, acknowledges the limit, yet does not give up on life as such; even more - as Derrida says in his last seminar, already aware of his terminal cancer diagnosis - he does not want to be "robbed of life's finitude." This formula, to be robbed of one's finitude, suggests that, indeed, death must be "very good": a treasure not to be easily taken away by

5 SR, 9-10; my emphasis.

6 Derrida could not be clearer on this point, reminding us that "this absolute evil (which is, is it not, absolute life, fully present life, the one that does not know death and does not want to hear about it) can take place." Jacques Derrida, Specters of Marx: The State of Debt, the Work of Mourning, and the New International, trans. Peggy Kamuf (New York: Routledge, 1994), 220; my emphasis.

7 Jacques Derrida, The Death Penalty, vol. 1, trans. Peggy Kamuf (Chicago: University of Chicago Press, 2014), 256. 
the promise of conquering death, offered by Pauline Christianity. We will find something very similar in late Adorno too, in his beautiful meditations on Goethe written just a few months before his death, devoted to the idea of reconciliation with nature, and most of all with the natural condition of finitude. The ultimate redemptive gesture, he says, is to "yield, but with no self-denial": to accept the finis, yet without giving up on a life spent dreaming of happiness and fulfillment. This is what Adorno explicitly calls by the theological term "redemption."

In all of these thinkers drawing on the "sources of Judaism" in their polemic with Christian overestimation of immortality, the same motif repeats itself over and over again: redemption - yes, but within the finite life. The infinite yes, but not beyond, rather internal to finitude. But how is this to be achieved? Isn't it precisely what Hegel calls the "living contradiction"?

The image of the finite life as a potential "infinite in the finite" or a "living contradiction" appears for the first time in Hegel. For Hegel, the living contradiction cannot be endured as such: life, deeply aporetic in itself, inaugurates the dialectical process, the goal of which is to solve the original aporia, or, in Hegel's own words, the reconciliation of the infinite and the finite. This reconciliation, however, cannot be achieved in life itself; in order to properly embrace the infinite, life must be sublated into the higher element of the spirit, which, unlike life, is capable of looking the negativity of death straight in the eye. Therefore, as long as life is an existing and abiding, not yet reconciled contradiction, its dominant manifestation is pain:

Pain is the prerogative of living natures; because they are the existent Notion, they are an actuality of infinite power, such that they are within themselves the negativity of themselves, that this their negativity is for them, and that they maintain themselves in their otherness. It is said that contradiction is unthinkable; but in fact, in the pain of a living being it is even an actual existence. ${ }^{9}$

8 See Theodor W. Adorno, "On the Classicism of Goethe's Iphigenie," in Theodor W. Adorno, Notes to Literature, vol. 2, trans. Shierry Weber Nicholsen (New York: Columbia University Press, 1992), 170: "Iphigenie's metaphor of exhaustion is learned from nature. It refers to a gesture that yields instead of insisting on its rights, but without self-denial."

9 G. W. F. Hegel, Science of Logic, trans. A. V. Miller (London: Allen and Unwin, 1969), 770; my emphasis. 
But if, in case of life, contradiction not only is thinkable, but also actual, then perhaps it would also be possible to suspend the teleology of reconciliation - the solution to the human paradox - and maintain oneself in it? After all, Hegel himself says that pain is a prerogative: not just a drawback or imperfection to be removed by higher stages of thought, but a positive moment - the moment of the birth of dialectics. Finite life, therefore, is the bedrock of the dialectical method and the proof of its validity as well; pace the commonsense belief that contradiction is unthinkable, every living thing "as such" demonstrates its painful, seemingly impossible actuality. The Hegelian "life-in-pain" constitutes the punctum crucis, but also - theologically speaking - a cross on which life's infinite power simultaneously incarnates itself, suffers, and dies. Yet, pace Hegel - after all a Christian thinker of resurrection, even if in the most heterodox forms - Rosenzweig will attempt to endure in what the former sees as an unbearable condition of the "disappearing moment" that triggers the dialectical process: a process that, in Hegel's version, takes the form of the salvific escape from life into a higher form of the Spirit, but within the "negative dialectics" as proposed by Rosenzweig (why not see him as a precursor of Adorno?), stays and remains in life. On this alternative reading, the prerogative of pain should not be too easily superseded because it carries an equally crucial message: that every finite life suffers because of its unfulfilled wish of "more life," or that despite its finitude it still wants to be redeemed - to get out of the condition of transience, which condemns it to death and oblivion, into eternity, which will not have to be the same as personal immortality, perpetuating $m y$ - singular and isolated - life forever. The pain is thus a privilege: it is a living question that wants to know whether the finite can somehow contain the infinite, become more life within mere life, i.e., in the paradigmatic formulation of Martin Luther, later bequeathed to Hegel and then to Rosenzweig: is finitum capax infiniti? Is the finite capable of bearing the infinite?

Rosenzweig claims that indeed it is: the finite can contain the redemptive infinite within itself without questioning its limits. For Rosenzweig, the Jewish formula love-strong-as-death defines love precisely as a corrective force that can be revealed only after the painful knowledge of death. While death is the seal of the creaturely transience that pushes all things into the dark and irretrievable past, love constitutes a power of "presencing" - of making them visible as bright phenomena "in the light of the divine countenance":

As keystone of Creation, death imprints everything created with the indelible stamp of its condition of creature, with the words "has been." But love declares war on it. Love knows only the present, it lives only out of the present, aspires only to the present. The keystone of the dark vault of 
Creation becomes the foundation stone of the bright house of Revelation. For the soul, Revelation is the lived experience of a present that, though resting on the existence of the past, does not dwell in it; on the contrary, this present walks in the light of the divine countenance. ${ }^{10}$

In his variation on, as well as deviation from the Hegelian theme, Rosenzweig maintains that it is not the death-bound Spirit but the life-loving Soul that can solely abide in the "living contradiction." Yet, the gentle touch or small voice, bat kol, of love means nothing to those who did not experience the disintegrating power of death. It can only come as the "second birth" of the Selfhood after it became deadened in the traumatic process of mortal isolation, for, as Rosenzweig says: "Only that which is singular can die, and everything that is mortal is solitary". ${ }^{11}$ This is why, for Rosenzweig, the deadly stage of the tragic hero, in which man severs his communal relations and "dies for the world," is indispensable in the process of revelation - just as the nihilistic stage of modern disenchantment, in which man withdraws his living participation from the deadened cosmic nature, is necessary to hear the "small voice" of Judaism as religion of the finite life: the more modest post-atheistic kind of faith that does not promise immortality, but only (only!) singularity capable to enter into intense relations with other singularities as its neighbors. In The Star of Redemption, the eternal relevance of Judaism lies precisely in that: once the great voice of Neoplatonic Christianity begins to wane due to the process of modern disenchantment, Judaism offers itself as a religious solution to the (re)discovery of human finitude - proposing its own re-enchantment of faith, hope, and love, but not staking them on the promise of spiritual immortality. The Star, therefore, contains a positive alternative to the negative and death-oriented philosophical accounts of finitude, which stem from the Kojèvian-Heideggerian, thanatic strain: the "awakening of the Judaic tradition" means also awakening to a new sense of life after the slumber of the virtual death caused by the sudden demise of the hopes of immortality. While the thanatic philosophical account of finitude can, in Rosenzweig's words, "only recommend suicide", ${ }^{12}$ his New Thinking aims to reflect the primordial wish of every living being "to stay, to live." Hence, just as the Rosenzweigian tragic hero, who became intimately acquainted with death, can solely acknowledge the principle of love-strong-as-death, so perhaps are we, late modern people, thoroughly immersed in the thanatic disenchantment of the twentieth-century philosophies of finitude, ready to appreciate the "small-voiced" proposition of

\footnotetext{
10 SR, 169; my emphasis.

11 SR, 10.

12 SR, 10.
} 
"another exit from the impasse of the nothing than this fall into the yawning of the abyss" (SR, 10). We are not asked by Rosenzweig to discard our knowledge of negativity altogether. Quite to the contrary, another finitude is based on the trauma of negativity, by offering its Durcharbeiten: a working-through in which finitude gradually loses its traumatic aspect and emerges under other auspices - no longer the closure of deadly fear, but the opening of love that gradually overcomes the solitary isolation of every singular life and individuates in a different manner:

The bond of the complete and redemptive tie between man and the world is, at first, the neighbor, only and constantly the neighbor ... [Love] slides from one carrier to the other, to the one that comes next, from one neighbor to the next neighbor, and it is not at rest before it has made the whole circuit of Creation. But it only apparently surrenders its power to the plural; in reality, it leaves traces of this wandering from place to place by introducing everywhere, into the plural of things, the sign of singularity. ${ }^{13}$

But this process of "sliding from one carrier to the other," this gradual pacing of "the whole circuit of creation" cannot happen all at once, for no shortcuts are allowed here; no jumps to general categories that would circumvent the singularity of every concrete neighbor that the Rosenzweigian love encounters. One cannot love all at one stroke, cannot embrace anything and everything in one timeless loving gaze - as is the case with Spinoza's amor intellectualis. This love is neither abstract nor intellectual: it is a strictly nominalistic affect for each and every thing/neighbor stepping one by one from isolation into relation. Love, therefore, is a lifelong, continuous, and always incomplete process of solving the "living contradiction" between the infinite and the finite - between the fear of the earthly and the love for the earthly - where the endlessly open, transitional, and relational nature of love offers a dynamic synthesis in the form of in/de/finity: not the infinity of essence or an immortal soul, which human life does not possess, but the infinity of "un-essence," that can fall for - and thus become, if only for a moment of bonding - anything and everything. If, according to Heidegger, a life of "un-essence" is Verfallenheit, then indeed the finitude spent under the sun of love is constantly falling: falling-in-love with all the things it cares for, simultaneously taking them in and pouring itself out on them, becoming all of them in the process. ${ }^{14}$

\footnotetext{
13 SR, 252.

14 On the difference between Rosenzweig and Heidegger regarding the issue of the finite existence and its propensity to fall (in love), see my Another Finitude: Messianic Vitalism
} 
The redemptive moment of love, therefore, lies not in the infinite intensity - the concentrated immortal essence of the individual called first the Self and then the Soul - but in the potentially infinite extension: in the bond, gliding from one bearer to another and eventually pacing the whole orbit of creation. The "beloved" as the passive object of the Revelation must transform into a "lover," an active agent of loving:

For in the world, it is not a matter of being loved, and he who is loved must behave as if it depended only on himself and as if he was not loved, and as if all his love was not being loved, but - loving. And when the soul emerges from the miracle of divine love to enter into the earthly world, it is only in the most secret place of its heart that it will be able to preserve the word of the ancients which gives strength and a blessing for what it still must do, through the memory of what it experienced in that magic circle: As he loves you, so shall you love.... It is a commandment of love like the original commandment of Revelation that accompanies all the single commandments and that alone removes from them the rigidity of laws and makes them living commandments.... Love for God must be externalized in love for the neighbor. ${ }^{15}$

We could thus say, following Rosenzweig's grammatical analysis, that the grammar of the commandment to love is the Hebrew mode of niphal, which marks the dialectical passage between passivity and activity: "blessed in order to bless" and "loved in order to love." What makes niphal special in this context is that it is deliberately asymmetrical. Instead of building a short-circuit relation of reciprocity in the manner of do ut des (I give you so you give me back), it breaks the "magic circle" and draws an open-ended line of constant transition and - as Derrida would have called it - dissemination of the gift. Thus, just as God blessed Abraham so he could then bless nations of the world, God now loves the beloved Soul so that she can love creatures of the world, and not turn toward God himself. As he loves you, so shall you love commands a break of symmetry, because only in this manner the blessing of love can get beyond the closed circle of being loved and loving in return, and become a "seed" of a new relation between the creatures. The nature of Revelation is that it must spread, and it is only in the "disseminatory" grammar of niphal that it can be achieved.

and Philosophy (London: Bloomsbury, 2019), especially the chapter "Falling - in Love: Rosenzweig Versus Heidegger," 39-74. 
It is therefore the Saint - not the Mystic, the heir of the tragic condition of isolation - who is the true "servant of his God," because he realizes that "love for God must be externalized in love for the neighbor" (SR, 230): it must leave the enclosure of the Self, which Hegel calls "the beautiful soul" of radical intensive inwardness, and find a way out toward Entäusserung: the outward expression as well as extension. ${ }^{16}$ In order to secure this passage - from the Mystic, who defines himself as an object of divine love and thus cuts himself off from the whole world, to the Saint, who, according to the niphal grammar of love, is loved by God only to love the worldly creatures - Rosenzweig resorts to the Lukacsian topos of visibility, coined in the famous essay "Metaphysics of Tragedy," from which the treatment of the tragic hero in the Star largely derives. According to Georg Lukács, due to all his exceptional suffering and isolation, the tragic hero makes himself visible to the gods and, in this manner, manages to awaken the hidden God, who slumbered after the grand work of creation, and force him to act again. The divine revelation becomes thus a response to the miracle of the heroically acquired metaphysical visibility which, as we already saw, draws things out of the darkness of the past and allows them to "present" themselves "in the light of the divine countenance": 17

But the miracle is fulfilment. It snatches from life all its deceptive veils, woven of gleaming moments and infinitely varied moods. Drawn in hard and ruthless outline, the soul stands naked before the face of life. Only the miracle, however, has reality before the face of God. For God there is no relativity, no transition, no nuance. His glance robs every event of all that

16 Hegel diagnoses the syndrome of a "beautiful soul" in the chapter devoted to morality understood primarily in Kantian terms as a rigid dualistic opposition of "what is" (nature) and "what should be" (duty) that can never be bridged, which, according to Hegel, leads to a generally hostile acosmic attitude toward reality as inherently evil. By championing a pro-cosmic form of moral action, Hegel writes against Kant: "on the contrary, pure duty, as also the Nature opposed to it, are [merely] superseded moments. Spirit is, in an immediate unity, a self-actualizing being, and the action is immediately something concretely moral.... Action qua actualization is thus the pure form of will - the simple conversion of a reality that merely is into a reality that results from action, the conversion of the bare mode of objective knowing [i.e., knowing an object] into one of knowing reality as something produced by consciousness." G. W. F. Hegel, Phenomenology of Spirit, trans. A. V. Miller (Oxford: Oxford University Press, 1977), 385. Note that Hegel uses here the religious term conversion precisely in the sense in which it was also used by Benjamin Pollock in his interpretation of Rosenzweig's own attempt to "overcome [the] Gnosticism" of his earlier Marcionite-dualistic leanings. Benjamin Pollock, Franz Rosenzweig's Conversions: World Denial and World Redemption (Bloomington: Indiana University Press, 2014). 
is temporal and local about it. Before God, there is no difference between seeming and substance, appearance and idea, event and destiny. The question of value and reality loses all its meaning: before the face of God, value creates reality and does not have to be dreamed or imagined as reality. This is why every true tragedy is a mystery play. Its real, central meaning is a revelation of God before the face of God. The god of nature and destiny, who is always speechless and always unredeemed, brings forth the voice of the god who slumbers inside man, the voice which, in life, has fallen silent; the immanent god awakens the transcendental god into life. ${ }^{18}$

Already in Lukács we see a germ of Rosenzweig's later fully developed dialogic method in the eternal interplay between God, Man, and World: while in the always past night of creation, World remains invisible to the God who retreats after his creationist deed into his inner darkness, it then produces a tragic hero who becomes visible to the God and makes him answer with the divine visibility of Revelation. Rosenzweig's stress on the constant dialogic interplay is to counteract the tendency toward hermetic self-enclosure, which Hegel diagnosed as the problem of the "beautiful soul," too much in love with its own righteousness to notice the real messy world, later on also criticized by Hannah Arendt as the syndrome of an "acosmic love," encompassing both the dangers of mysticism and the isolation of a passionate romance that makes lovers oblivious to worldly affairs. ${ }^{19}$ Just as God the Creator must be constantly "awakened" and pushed into dialogue against his own inclination to sink back into his hidden existence (the Schellingian "dark ground of being”), so, too, the beloved Soul must be "awakened" from its internal bliss:

In the bliss of love received from God, the soul that had merely surrendered has no feeling for the world, or rather for anything outside of God. Just as the mere Creator is always in danger of sinking back again into his hidden existence, so, too, the pure bliss of the soul engulfed in God's loving look is in danger of returning to its enclosure. It is enclosed man who, like the hidden God, stands at the frontiers of Revelation and separates it from the primordial world ... the hero must become a visible figure, he must be in the world, even if he himself does not know it and does not

18 György Lukács, "Metaphysics of Tragedy," in György Lukács, Soul and Form, trans. Anna Bostock (London: Merlin Press, 1974), 153-154; my emphasis.

19 Much of The Human Condition is devoted to the critique of the "worldless affect ... which cannot withstand the implacable, bright light of the constant presence of others on the public scene." Hannah Arendt, The Human Condition (Chicago: University of Chicago Press, 1998), 51. 
want to admit it; and the feeling that things are like this is what the chorus compels the spectator to recognize; the chorus that gazes upon the hero listens to him and calls out to him to answer.... Man defined only as an object of divine love is cut off from the whole world and closed in himself. ${ }^{20}$

The last line refers to the Mystic: in Rosenzweig's system, the Mystic is an emblematic figure very much parallel to the Hegelian schöne Seele, determined mostly by its isolated inwardness and a contempt for the creaturely finite world which the Mystic refuses to perceive as the divine creation. The Mystic, therefore, can be a sectarian Gnostic (indeed, a prototype of the "beautiful soul" for Hegel), who treats the world "as if it was created by the devil," but he can also stand for a modern Nihilist who treats the world "as if it was put at his disposal." The refutation of the Mystic in The Star, therefore, plays a very significant role in Rosenzweig's "overcoming of Gnosticism," which, as Benjamin Pollock proved very convincingly in his recent book, meant also a strategy of self-therapy, allowing Rosenzweig to quit for good his own Marcionite temptation to see the finite, death-touched world as, indeed, made by a lower Archon drawing from evil demonic powers, and not created by a loving God. ${ }^{21}$

20 SR, 222-223; my emphasis.

21 In the first chapter of Franz Rosenzweig's Conversions, "Revelation and World Skepticism: Rosenzweig's Early Marcionism," Benjamin Pollock sketches a history of the "overcoming of Gnosticism" that constituted an important development in Rosenzweig's intellectual career. Referring to the conversation with Eugen Rosenstock in Leipzig in 1913, Pollock writes: "In later reflections, Rosenzweig identifies the world-denying theological standpoint with which he entered the Leipziger Nachtgespräch as the standpoint of Marcion and the Gnostics. Gnosticism was the name under which scholars of Rosenzweig's day categorized a cluster of theological positions that shared the view that the individual's spiritual self is trapped in a world of deception, and that his salvation lies solely in a kingdom that 'is not of this world.' Scholars of Rosenzweig's day understood the myriad forms of ancient Gnosticism to share a commitment to metaphysical dualism, according to which the world was understood to be not the creation of a benevolent God, but rather the work of an inferior, but quasi-independent, divinity, a Demiurge often depicted as evil and deceptive. According to this view, however, beyond our world of illusion and trouble, there is a truly good and merciful God, who awakens those few endowed with 'spirit' in the world to the nature of their predicament, and provides them with the knowledge (gnosis) necessary to enable their spiritual selves to escape the world's confines... The problem was that [Rosenzweig] found God accessible only through revelation [emphasis in original]. And this left the status of the world - its metaphysical grounding, its value, its relation to the 'God of revelation' - in doubt. Was the God of revelation and salvation also the God of creation? Or was revelation the means through which the human being could be freed or redeemed from the world, a world not created by the God of revelation? [my emphasis, with Pollock's emphases in bold]." Pollock, Rosenzweig's Conversions, 18, 20. 
If the Mystic is to be rejected, it is

because he wants to be absolutely nothing other than God's favorite. In order to be so, in order, that is, to see nothing other than the one track running from God to him and from him to God, he must deny the world, and since it will not let itself be denied, he must actually dis-own it; it is not by chance but rather absolutely essential for him that he treat the world, since it is very much there, as if it did not really "exist," as if it did not have being-there or already-being-there; he must treat it as if it were not created (for that is precisely its being-there!) as if it were not a creation of God, as if it had not been placed there for him by the same God whose love he claims; it is not that he can, but that he must treat it like a world created by the devil; or, since it seems impossible to reduce this notion of Creation to an act of the devil, we should say rather that he must treat it as if it were not created, but instead put at his disposal, just to provide for needs of the immediate moment when he grants it a glance. This relationship of the pure mystic with the world, which is fundamentally an immoral relationship, is absolutely necessary for him, if indeed he wants to confirm and safeguard his pure mystical state. The world necessarily closes itself off to the closure of the arrogant man. And man, whom we have already seen open up, instead of coming alive as speaking figure, is swallowed up again in his enclosure. ${ }^{22}$

The arrogance of the Mystic/Gnostic/Nihilist consists precisely in the rejection of finitude: in not being able to see that death is not evil, but, to the contrary, "very good." The rejection of death as the defining moment of finitude equals the rejection of the idea of creation; either by denying, in the Marcionite manner, the identity between God the Creator and God the Redeemer or by negating the creaturely purpose and degrading the world to the instrumental status of a resource. It is, therefore, not the Mystic, who dies for the world, but the Saint who truly gets the divine message of love. The role of the Saint is to become metaphysically visible and elevate the creaturely world out of its darkness into the light of the Day of the Lord by the power of active loving.

In his choice of the Saint, Rosenzweig revises Lukács's metaphysics of tragedy, by delegating the virtue of a true visibility only to the Saint who, in his account, becomes an incarnation of the Goethean ideal of complete humanity (All-Mensch), "toward which the Faustian tragedies only strive without ever attaining it, because they always stay mired in limited life". ${ }^{23}$ This allusion to

22 SR, 223-224; my emphasis.

23 SR, 227. 
Goethe's self-professed "paganism," otherwise admired by Rosenzweig, indicates that the tragic hero is only a limited version of the "full man" that can only be achieved by the Saint. The triad - the Tragic Hero, the Mystic, and finally, the Saint - mark the dialectical process of first being-in-the-world, then losing-the-world, and, in the end, recovering-the-world: while the tragic hero simply is in the primordial world, and the Mystic forfeits the world in the process of Entweltlichung, typical of the acosmic stage of religious infatuation with God, the Saint finds the world again in an ana-cosmic gesture, which follows the asymmetrical passive-active grammar of love as "being loved in order to love." He experiences the divine love not as a signal to abandon worldly reality and focus on God solely, but as a signal to abandon God as the object of active loving and shift it toward the worldly objects - finite, incomplete, and precisely because of that calling for the completion in the act of love. The anacosmism - returning to the world and accepting it as finite after it had been rejected due to the Revelation of the divine infinite - is thus the defining feature of the Saint. The Saint knows the infinite dimension, yet does not oppose it rigidly to the finite, which constitutes the error of the Mystic, "who certainly stands opposite the 'Absolute,' but, at base, only opposite"; ${ }^{24}$ he rather lives the Infinite in the finite mode: "absolute man would have to live in the Absolute": 25

The hero was a man, if only in the primordial world. But the mystic is not a man, he is scarcely half a man, he is only the vessel of the raptures he feels. He speaks, certainly, but what he says is only answer and not word, his life is only waiting and not walking forward. But only a man in whom the answer would give rise to the word, in whom the waiting for God would give rise to walking before God, only he would be a true man, fully a man. Only he could counterbalance the hero; for only he would be visible, only he would be as much a figure as the hero is ... This point of convergence where all the lines of every tragic character meet, this absolute man who not only knowingly stands opposite the Absolute, but who has experienced it in his life and who, from this experience, lives in it ... is none other than the saint.... The saint is the perfect man, that is to say, he who lives absolutely in the Absolute, the man open to the highest things and resolute in the highest actions, in contrast to the hero who is always enclosed in the same darkness of the Self. In the place assumed by the lord of his Self in the primordial world [i.e., the tragic hero], there appears, in the new world constantly renewed, the servant of his God. ${ }^{26}$

\footnotetext{
24 SR, 226.

25 SR, 226.

26 SR, 224; 227; my emphasis.
} 
But it is not just Lukács who provides Rosenzweig with inspiration here. In his account of love as dynamic and plastic, all-reaching and all-binding connection, Rosenzweig relies heavily also on German Romanticism: Hölderlin's "bonds of love" (Liebesbände), also Novalis, but most of all Goethe, who famously said that "love connects all" (Liebe verbindet alles) and that "if you want infinity, go in all directions of the finite." We will find the same romantic wisdom in Novalis's apothegm: Die Basis aller ewiger Verbindung ist eine absolute Tendenz nach allen Richtungen (The ground of all eternal connection is an absolute tendency in all directions). ${ }^{27}$ Rosenzweig's love is precisely such an attempt in all directions, the purpose of which is to turn - metamorphose the monolith of being, organized hierarchically according to general categories, into a horizontal community of the "numberless singulars," capable to relate to one another in the new way that is the "eternal connection." It is thus not the singular essence of a thing that is capable of achieving eternity, but only a singularity entangled in the "bonds of love" with its neighbors, together forming a constellation that transforms the world, by pushing it toward metaphysical fulfilment, being at the same time full visibility: "God and man already are, the world is becoming. The world is not yet complete". ${ }^{28}$

The eternity, therefore, that in Rosenzweig's system replaces personal immortality, is precisely the Novalisian "eternal connection" that, far from being a fleeting moment of merely subjective experience, contributes to the very creation of the world: to its emergence out of the indifference into the "growth of life," which Georges Canguilhem, the best philosopher of life after Bergson, defines precisely as the "attempt in all directions." ${ }^{29}$ The bonds of love, which connect anything to anything - from the ordinary acts of neighborly love, through the speech acts of calling and addressing, which leave traces of the "eternal connection" in language, to the more modest variant of the Spinozist amor intellectualis, which holds potential singularities in one loving gaze - not only foster and accelerate the growth of life, but also anticipate the redemptive stage of world's full being. In Rosenzweig's variation on Wordsworth's "Intimations of Immortality," love is the "eternal connection" that allows "what ever was to ever be," yet not through granting each thing

\footnotetext{
27 Novalis, Werke, Tagebücher und Briefe Friedrich von Hardenbergs, ed. Hans-Joachim Mähl, Richard Samuel, and Hans Jürgen Balmes, 3 vols. (Munich: Carl Hanser, 1987), 2:445.

28 SR, 235.

29 Georges Canguilhem, Knowledge of Life, trans. Stefanos Geroulanos and Daniela Ginsburg (New York: Fordham University Press, 2008), 90.
} 
an immortality in isolation, but only in the fulfilled eternal configuration of the world:

Every neighbor who appears unexpectedly must be an "any" thing, a substitute of every other one and of all others; he is not permitted to ask questions or to differentiate: it is his neighbor. But from the world's point of view, it is on the contrary man's act of love that is the unpredicted, the un-hoped for, the big surprise. It is in itself that the world carries the law of its growing life.... The world knows only, or thinks it knows, that all life must die. And when it desires eternity, it does so by waiting for an intervention from outside that will procure immortality for life.... It is only when and where the members of this living organism are covered by the breath of love for the neighbor, a breath that breathes soul into them, it is only when they add to their life what life itself could not give them: a soul, eternity. The act of love therefore only apparently is effective on the chaos of an "anything." In truth, without knowing it, it presupposes that the world, all the world with which it has anything to do, is growing life. ${ }^{30}$

Although Rosenzweig uses here the phrase "immortality for life," it serves as a synonym of eternity understood as the negation of the fleeting transience or "dying" already inscribed in the configuration of the world growing life. Life knows it is going to end in death, but this is not a purely negative knowledge. "Death is very good" means that the world-life cannot close upon itself in selfsufficiency, but must open to love as the touch of the infinite: all the living must be loved, affirmed in its desire "to stay, to remain" and thus made visible to the loving gaze as the agent of divine infinity. It is through the loving gaze, therefore, that all singular things become visible to God, and although they will die in the natural course of events, they, being recognized and acknowledged, are already inscribed into the Book of Eternal Life. Once again, the Lukacsian motif of visibility appears crucial here: to acquire a soul, breathed in by "the breath of love for the neighbor," means to "stand, drawn in hard and ruthless outline, naked before the face of life."31 It does not indicate immortality as an ontological cancellation of death, which would allow the singular life to go on forever; rather, it announces an eternalization mediated by the loving address. God can see everything only through the human acts of neighborly love.

$30 \quad$ SR, 258; my emphasis.

31 Lukács, Soul and Form, 153. 
It is thus thanks to love that "the seed of eternal life has been planted": ${ }^{2}$ the infinite is no longer opposed to the finite, life no longer "stands opposite the Absolute" but now "lives in the Absolute". ${ }^{33}$ By securing the "eternal connection" of all worldly things/neighbors, by covering them with the net of love, the Saint acts as the agent of eternity: himself already eternalized / made visible in the moment of Revelation, he also anticipates the advent of Redemption in which the whole world will have become an all-connected community of souls. The redemption of the human being, therefore, lies not in the solitary gain of spiritual immortality, but in the messianic practice of mending the world, which consists in what E. M. Forster defined as one chief imperative only connect. But since even the Saint cannot pace the whole orbit of creation by himself; since even he can only love "many" and never "all," the redemption of the human individual remains always a potentiality never to be fully realized. Although redeemable, she can never be redeemed in actu - and the same counts for the world. What the human singular can lovingly do to her singular neighbors amounts to a mere anticipation of the redemptive finale in which the whole world will have been lifted out of darkness into light, by the power of the "all-connectedness," bringing all small private lamps into the splendor of one sun, the Day of God. The limited, "weak messianic power to which the past has a claim" that belongs to the individual human can only leave a trace of light, a fleeting flash of "many" - but never all - sparks linked together within the creaturely night; it cannot, however, lift the whole world into the sunlight for good. This Benjaminian term, coined in Theses on the Philosophy of History, is already fully operative in Rosenzweig avant la lettre. ${ }^{34}$ To possess a weak messianic force means that it is not in our power to save the world, but it is in our power to remind the world of its essential saveability. But that also means the same for this meta-ethical remnant who becomes active in the world as the Saint: to be saved in potentia, be redeemable. While the horizon of Erlösung is already staged, neither the Saint nor the World can ever cross the line of the full messianic actualization. All that can actualize itself here and now is an active anticipation of the redemptive fulfilment.

This is precisely why Rosenzweig needs We: a community of connected souls, akin to the Lurianic kneset Israel, which will have reconstituted the divine countenance as a lasting eternal Gestalt within the world - "We, the Eternal People". ${ }^{35}$ Whatever had been brought out of the pre-worldly darkness

\footnotetext{
32 SR, 355 .

33 SR, 226.

34 Walter Benjamin, "Theses on the Philosophy of History," in Illuminations: Essays and Reflections, trans. Harry Zohn (New York: Schocken, 1968), 254. 
and lit up, even if for a second of the mundane time, enters the after-worldly configuration of truth and eternity, which, as in the kabbalistic teaching, outlines the Face of God:

That which is eternal had become configuration in the truth. And truth is nothing other than the countenance of this configuration. Truth alone is its countenance.... This shining of the divine face alone is truth. It is not a configuration freely moving for itself, but only God's countenance lighting up. ${ }^{36}$

For, although the state of redemption can only be anticipated, there are degrees of this approximation, and the ritual Lebensform of Judaism is already one foot in the Day of God. Strictly separated from the pragmatic concerns of everyday life, free from the Christian political theology, Judaism, the religion of people without land and politics, is a Platonic image of eternity in this world - "an earthly simile of the eternal" 37 - and, because of that, a guardian of the otherworldly "fire [that] burns in the heart of the Star". ${ }^{38,} 39$ Without Judaism and its believers who safeguard the transcendence of Revelation, Christianity would thus sink completely into the temporal immanence, which would also mean a collapse of the tripartite division of the elements - God, Man, World - into a new pantheism, as it happened in the system of Hegel, who all too easily "reconciled heaven and earth" 40 and thus lost the perspective of eternity. For, the "all divinely-supra-terrestrial immortalization of the moment" ${ }^{41}$ can proceed only from the communal ritual that prepares

36 SR, 441.

37 SR, 310 .

38 SR, 317 .

39 The anticipatory maximum which, according to Rosenzweig, characterizes Judaism, is very well described by Karl Löwith in his defense of eternity against temporality: "The temporality of the earthly life does not for the Jewish people imply a life and death struggle with the fate of the world, but wandering and waiting and anticipating the consummation in every moment it does not know real growth and decay. The whole world, the history of states, wars, and revolutions loses that seriousness and weight in the eyes of the Jew that it has for the other peoples; for to 'God's people' eternity is always present whereas the other peoples need the state, its laws, and power in order to bring time to a short stop and to secure for themselves a relative eternity." Karl Löwith, "M. Heidegger and F. Rosenzweig or Temporality and Eternity," Philosophy and Phenomenological Research 3 (1942): 72 .

$40 \mathrm{SR}, 13$.

$41 \quad$ SR, 309. 
temporal dwellings into which the eternal is invited. In the daily-weeklyyearly repetition of the cycles of prayers of worship, faith makes the moment into the "hour" and time ready to receive eternity; and eternity, by finding a reception in time, itself becomes - like time.... God cannot do otherwise; he must accept the invitation. ${ }^{42}$

Without land and politics, "the community of the same blood alone feels even today the guarantee of its eternity running warmly through its veins": ${ }^{43}$ the key to the eternalization of the Chosen People is the communal We as the "succession of generations, each of which begets the following one, as it itself again will bear witness to the preceding one". ${ }^{44}$ It is, therefore, not the individual Saint who truly embodies "the infinite in the finite," but only the crossgenerational community of Saints, which can ultimately defy death as the seal of the creaturely world, attempting to end all living before it can reach the Day of the Lord:

Death had wanted to reap all life so that it would not live until the eternal end. It boasted that every end is only to be achieved by dying. In the eternal people, triumphantly opposed to this is the fact that the end can also be reached by living. There the Reaper's scythe breaks. ${ }^{45}$

Despite the similar rhetoric of triumphant victory, this is not the Pauline conquering of death, which would promise personal immortality and turn death into a gate leading to life immortal. Judaism proves that "the end can also be reached by living," i.e., in life and through life, provided it itself becomes a gate to - and invitation of - eternity. Yet, death still remains "very good" because "the created death of the creature is at the same time the sign that announces the Revelation of life which transcends that of the simple creature"; 46 without that sign, there would be no desire for eternity and thus no awakening of the eternal life into dialogic self-consciousness. Without the death-sign, this master signifier of the creaturely condition, the world would not have known that it is finite - and God would not have known that He is infinite. ${ }^{47}$

42 SR, 310; 312.

43 SR, 317.

44 SR, 317.

45 SR, 416; my emphasis.

46 SR, 168.

47 The importance of being a creature, an entity created by God and thus made finite, is also very strongly emphasized by Pollock as part of Rosenzweig's own wrestling with his 
It is well known that Gershom Scholem, who always insisted that the Jewish messianic idea demands a concrete vision of redemption capable to occur in earthly conditions, felt deeply disappointed with this result and accused Rosenzweig of the "church-like" neutralization of the apocalyptic element in Judaism. The Star, says Scholem, forms a "clock-work mechanism" that functions as a "lightning rod" against the messianic blaze: it brings it to the ground and dissipates it - or, in the terms of the above analysis, it weakens the actuality of redemption into a mere potentiality. ${ }^{48}$ Yet, within the system of the

earlier Marcionite world-denial: "We are called on to remain in the fear of earthly, to overcome the temptation to world denial, to affirm divine truth through redemptive action in the world, Rosenzweig suggests, because and insofar as we are creatures." Pollock, Franz Rosenzweig's Conversions, 214. This can also explain why Rosenzweig, although inimical to the "idealism" of spiritual immortality, inclines toward the resurrection of the bodies, which maintains the psycho-physical unity of the singular finite existence and restores the condition of finitude. This repetition could thus be read as an extra confirmation: twice-finite or once-again-finite, the resurrected body would be gloriously reinstated in its creaturely finitude, no longer to be experienced as a defect or privation. In the letter to Hans Ehrenberg dated May 10, 1918, Rosenzweig argues against his "idealistic" cousin, who converted to Christianity seven years earlier, that "the immortality has been already known to the pagans. The novelty with which the pagan world clashes is thus not the immortality of the soul, but the resurrection of the body. You can see it in Augustine, and even better in Tertullian (De anima, De resurrectione carnis). 'Idealism' as such is a pagan invention. Revelation saves on all fronts the matter put in danger by the idealistic assault and gives matter back its right against the spirit, and, further: it empowers the soul against spirit, time against timelessness, space against concept, etc. And so it happens that the spiritual, all too spiritual idea of immortality, deeply anchored in the pagan reality, becomes replaced with the idea of the resurrection, linked to the 'flesh' and the course of history. What a laughing stock for a Platonist! But in truth: what a power of reality (Kraft der Wirklichkeit) against Plato. This body (Leib) - my body here and now - I cannot deny, either here or there. I cannot ignore one part of my being (Wesen), this most peculiar escape is blocked for me; I am I as a whole (ganz bin ich Ich) and as a whole will I be 'dispatched,' while this world in which I live is not something alien whose fate is indifferent to my happiness; on the contrary, the fulfillment of its destiny is the gate to my bliss (Seligkeit)." Franz Rosenzweig, Der Mensch und sein Werk: Gesammelte Schriften I: Briefe und Tagebücher. Band I (1900-1918), ed. Rachel Rosenzweig, Edith Rosenzweig-Scheinmann, and Bernhard Casper (The Hague: Martinus Nijhof, 1979), 558-559, my translation.

48 In his essay "On the 1930 Edition of Rosenzweig's Star of Redemption," Scholem writes: "The deep-seated tendency to remove the apocalyptic thorn from the organism of Judaism makes Rosenzweig the last and certainly one of the most vigorous exponents of a very old and very powerful movement in Judaism, which crystallized in a variety of forms. This tendency is probably also responsible for the strangely church-like aspect which 
Star, which is based on the complex multi-temporal metaphysics of Schelling, it is not a whim, but a necessity. Here all configurations - the Pre-World, the World, and the After-World - coexist eternally, never to be sublated in the dialectical process, but preserved in their various temporal tenses by the AND. ${ }^{49}$ The World, situated between the preworldly stage that knows no redemption and the fully redeemed afterworld, is thus forever redeemable: always already emerging out of the night of creation into the twilight of redemption, and always already approaching the sunlight of the Day of God. Accordingly, Man is, simultaneously, a tragic hero, when he discovers death; a lover, when he receives the light of revelation and spreads it through the creaturely realm; and the member of the communal We that has reached the eternal perfection of its ritual form of life.

Judaism unexpectedly sometimes takes on here." Gershom Scholem, "The Messianic Idea in Judaism" and Other Essays on Jewish Spirituality (New York: Schocken, 1995), 323. Although Scholem makes no allusions to Rosenzweig's early Marcionism, we could nonetheless paraphrase his objection by saying that, perhaps, he carried his "overcoming of Gnosticism" a bit too far.

49 Precisely because redemption can only be anticipated, human beings can never abstain from the redemptive work, which is also valid for the third part of the Star, where Rosenzweig talks about eternity. What is crucial here is the distinction between the work of redemption, which testifies to World's and Man's redeemability, and the state of redemption, which can be attributed only to God in shabbat: "Redemption is his day of rest, his great Sabbath, to which the Sabbath of Creation only points beforehand, the day where, redeemed from everything outside him that is again and again compared to the Incomparable One, he will be One and his name will be: One. Redemption redeems God because it frees him from his revealed Name.... The sanctification of the Name itself happens so that the Name one day may become silent.... Where other names no longer throw themselves opposite the one Name, where the one Name is all-one and everything created knows and confesses it and only it, there the work of the sanctification has come to rest" (SR, 242). The end here is devised not as a telos of Hegelian dialectics but as a separate condition of God himself, conceived within the Schellingian structure of simultaneity. For us, therefore, the work of redemption never ends: all we can do is spread the works of love through creation and anticipate the holy shabbat in ritual. 